\title{
Efektivitas Upah Minimum di Kabupaten Bandung
}

\author{
Elisa Susanti ${ }^{1}$
}

\begin{abstract}
Abstrak
Permasalahan upah minimum terjadi di berbagai negara berkembang, yaitu banyaknya pekerja yang dibayar tidak sesuai dengan ketentuan upah minimum. Fenomena tersebut mengindikasikan bahwa upah minimum mungkin tidak menjadi alat yang efektif untuk meningkatkan kesejahteraan dan sebagai instrument dalam distribusi pendapatan. Tulisan ini bertujuan untuk menganalisis efektivitas upah minimum di Kabupaten Bandung. Dalam tulisan ini akan dikaji apakah upah minimum efektif sebagai alat kebijakan untuk meningkatkan kesejahteraan. Dalam hal ini yaitu untuk memenuhi hakhak dan perlindungan upah bagi pekerja serta pada saat yang bersamaan dapat mewujudkan kondisi yang kondusif bagi pengembangan dunia usaha. Metode penelitian yang digunakan dengan pendekatan kualitatif. Hasil penelitian menunjukkan Upah minimum belum efektif sebagai alat perlindungan upah bagi pekerja/buruh di Kabupaten Bandung. Upah minimum dapat menjadi alat yang efektif bagi peningkatan kesejahteraan apabila terdapat upaya untuk mengatasi berbagai permasalahannya. Terdapat berbagai permasalahan kompleks yang memerlukan peran dari berbagai pihak, yaitu pemerintah, pekerja/buruh dan pengusaha.
\end{abstract}

Kata Kunci : Upah minimum, kesejahteraan pekerja/buruh, ekonomi sektor publik.

\section{Pendahuluan}

Pemerintah memiliki tiga fungsi utama dalam perekonomian sektor publik yaitu fungsi alokasi, fungsi distribusi, dan fungsi stabilisasi (Musgrave dan Musgrave, 1989) Distribusi merupakan fungsi pemerintah yang ditujukan untuk mengurangi ketimpangan pendapatan dalam masyarakat. Distribusi pendapatan dilakukan dengan prinsip efisiensi yaitu terdapat perubahan kondisi ekonomi untuk meningkatkan kesejahteraan. Efisiensi tercapai jika terdapat perubahan pada satu pihak namun tidak juga memperburuk keadaan pihak lain. Bagi sector publik, upah minimum merupakan salah satu instrument dalam distribusi pendapatan. Upah minimum dianggap sebagai kebijakan yang dapat memberikan kontribusi untuk keadilan sosial dengan meningkatkan upah bagi pekerja/buruh.
Beberapa penelitian mengenai upah minimum di negara berkembang menunjukkan bahwa banyak pekerja yang dibayar tidak sesuai dengan ketentuan upah minimum. Permasalahan upah minimum di Thailand adalah banyaknya pekerja yang dibayar tidak sesuai dengan ketetapan upah minimum. Menurut hukum perlindungan buruh di Thailand, upah minimum berlaku bagi pekerja baru dan pekerja yang tidak memiliki keahlian. Sehingga upah minimum sebenarnya hanya dibayarkan bagi sebagian kecil pekerja. Namun kondisi di Thailand menunjukkan banyak pekerja (sekitar 1.71 juta pekerja) dibayar dibawah upah minimum (Paitonpoong et.al, 2005). Bhorat dan Stanwix (2013) yang mengutip dari berbagai sumber, mengemukakan bahwa sebagian besar pekerja di negara-negara berkembang memperoleh upah di bawah minimum. Misalnya, di Argentina, hanya

\footnotetext{
${ }^{1}$ Dosen Administrasi Publik, Universitas Padjadjaran. Email: elisa.susanti@unpad.ac.id
} 
setengah dari angkatan kerja menerima hak-hak nya, yang meliputi upah di atas minimum, ketentuan mengenai jam kerja, dan kompensasi (Ronconi, 2008). Di Afrika Selatan diperkirakan bahwa di bawah setengah dari angkatan kerja menerima upah di bawah minimum, Berbagai studi lainnya juga menemukan fenomena yang sama, seperti di negara-negara Trinidad dan Tobago (Strobl dan Walsh, 2001), Brazil (Lemos, 2006), Chili (Kanbur, Ronconi dan Wedenoja, 2013) dan beberapa negara Amerika Latin lainnya (Maloney dan Nuñez, 2003; Gindling, Mossadd \& Trejos, 2013).

Berbagai fenomena di negara berkembang tersebut memunculkan kekhawatiran bahwa upah minimum mungkin tidak menjadi alat kebijakan yang efektif untuk meningkatkan kesejahteraan. Jones (1997) mengemukakan beberapa alasannya yaitu pertama, banyak pekerja sector informal yang tidak terlindungi oleh ketentuan upah minimum. Alasan kedua yaitu bahkan di negara-negara yang sebagian besar pekerjanya terlibat dalam sector formal, tidak ada jaminan bahwa upah minimum akan dilaksanakan dengan baik. Terdapat fakta bahwa perusahaan cenderung untuk menghindari ketentuan upah minimum. Di banyak negara berkembang, hukum upah minimum memiliki dampak yang kecil karena lemahnya penegakan hukum. Demikian pula, perusahaan tidak melaksanakan upah minimum karena nilai upah minimum yang tinggi yaitu ketika nilai upah minimum berada di atas keseimbangan pasar. Alasan ketiga yaitu, bahkan di negara-negara yang memiliki tingkat kepatuhan yang tinggi terhadap undang-undang upah minimum, terdapat efek yang tidak diinginkan yaitu dengan mengurangi permintaan untuk pekerja berketerampilan rendah. Efek ini terjadi karena perusahaan lebih memilih untuk mempertahankan para pekerja terampil yang upahnya telah meningkat, dibanding mengambil pekerja baru dengan mengikuti ketentuan upah minimum.

Tulisan ini bertujuan untuk menganalisis efektivitas upah minimum di Indonesia, dengan studi kasus di Kabupaten Bandung. Indonesia menetapkan upah minimum berdasarkan UU
Nomor 13 Tahun 2003 Tentang Ketenagakerjaan yang dijabarkan dalam Peraturan Pemerintah No 78 Tahun 2015 Tetang Pengupahan. Upah minimum merupakan upah bulanan terendah yang terdiri atas upah tanpa tunjangan atau upah pokok termasuk tunjangan tetap. Upah minimum hanya berlaku bagi Pekerja/Buruh dengan masa kerja kurang dari satu tahun pada perusahaan yang bersangkutan. Dengan demikian, upah bagi pekerja/buruh dengan masa kerja satu tahun atau lebih dirundingkan secara bipartit antara pekerja/buruh dengan pengusaha di perusahaan yang bersangkutan. Penetapan upah minimum bertujuan untuk melindungi hak dasar pekerja dan mewujudkan kondisi yang kondusif bagi dunia usaha. Berdasarkan penjelasan UU 13 tahun 2003 disebutkan bahwa : Pembangunan ketenagakerjaan harus diatur sedemikian rupa sehingga terpenuhi hak-hak dan perlindungan yang mendasar bagi tenaga kerja dan pekerja/buruh serta pada saat yang bersamaan dapat mewujudkan kondisi yang kondusif bagi pengembangan dunia usaha.

Kabupaten bandung merupakan studi kasus yang menarik untuk dilakukan analisis mengenai efektivitas upah minimum. Kabupaten Bandung merupakan salah satu daerah yang tergabung dalam Metropolitan Bandung Raya. Wilayah metropolitan ini merupakan wilayah cepat tumbuh yang mempunyai peran penting dalam membangun ekonomi. Sebagian besar wilayah Metropolitan Bandung Raya merupakan daerah industry. Kabupaten Bandung merupakan daerah yang memiliki sektor industri terbesar dibandingkan dengan daerah lainnya. Di Kabupaten Bandung sendiri, sektor industri ini menyumbangkan PDRB terbesar dibandingkan sektor lainnya. Peran sektor industri di Kabupaten Bandung adalah sebesar 50,67\% pada tahun 2011 menurun menjadi $49,77 \%$ pada tahun 2012, meningkat menjadi $50,80 \%$ pada tahun 2013, dan kembali meningkat menjadi $51,82 \%$ pada tahun 2014. Pada tahun 2015, sektor industri tetap merupakan penyumbang terbesar bagi PDRB Kabupaten Bandung namun mengalami perlambatan laju PDRB yaitu menjadi $4,32 \%$ pada tahun 2015 , dimana laju PDRB sebelumya adalah $6,66 \%$ pada tahun 2014 
(Sumber : Produk Domestik Regional Bruto Kabupaten Bandung Menurut Lapangan Usaha Tahun 2010-2014, BPS Kabupaten Bandung).

Nilai upah minimum Kabupaten Bandung mengalami peningkatan dalam setiap tahunnya dengan rata-rata kenaikan sebesar $16,25 \%$ per tahun (tahun 2012 sampai dengan tahun 2015). Namun tidak demikian halnya dengan laju pertumbuhan ekonomi Kabupaten Bandung yang mengalami perlambatan, yang dipengaruhi oleh perlambatan pada sector industry. Laju Pertumbuhan Ekonomi Kabupaten Bandung adalah $6,28 \%$ pada tahun 2012 menurun menjadi $5,89 \%$ pada tahun 2013 , menurun menjadi $5,88 \%$ pada tahun 2014 dan kembali menurun menjadi 5,47\% pada tahun 2015. (Sumber : Analisis Pembangunan Ekonomi Kabupaten Bandung 2015. BPS dan Bappeda Kabupaten Bandung).

Tulisan ini bertujuan untuk menganalisis efektivitas upah minimum di Kabupaten Bandung. Data awal menunjukkan bahwa nilai upah minimum mengalami kenaikan dalam setiap tahunnya, namun tidak demikian dengan nilai LPE yang cenderung mengalami perlambatan. Sehingga dalam tulisan ini akan dikaji apakah upah minimum efektif sebagai alat kebijakan untuk meningkatkan kesejahteraan. Dalam hal ini yaitu untuk memenuhi hak-hak dan perlindungan upah bagi pekerja serta pada saat yang bersamaan dapat mewujudkan kondisi yang kondusif bagi pengembangan dunia usaha.

\section{Kajian Teori}

Upah minimum merupakan instrument kebijakan yang digunakan oleh pemerintah untuk melaksanakan fungsi distribusi pendapatan. Gunderson (2005) mengemukakan bahwa se-bagai instrumen kebijakan, undangundang upah minimum dihadapkan pada berbagai tujuan yang saling terkait, meskipun sering dengan tujuan bertentangan serta motif tersembunyi. Namun demikian, penetapan upah minimum yang dilakukan pemerintah memiliki berbagai tujuan yaitu : (1) Mengurangi kemiskinan (2) Mengu-rangi ketidaksetaraan upah (3) Mengurangi pekerjaan berupah rendah (4) Memberi bantuan untuk pendidikan (5)
Melindungi pekerja yang memiliki daya tawar rendah.

Demikian juga dikemukakan oleh Eyraud dan Saget (2005) bahwa: "The main aim of the minimum wage is to protect the lowest-paid workers in order to guarantee them a decent standard of living". Perlindungan terhadap pekerja dengan daya tawar rendah tersebut dimaksudkan agar mereka dapat hidup sesuai dengan standar hidup layak.

Tujuan utama dari upah minimum adalah meningkatkan kesejahteraan pekerja. Konsep tenaga kerja tentu bervariasi dari satu negara ke negara lain. Demikian juga konsep kesejahteraan yang dapat didekati dari berbagai pandangan. John (2004) mengemukaan bahwa Labour welfare is an extension of the term Welfare and its application to labour. Todd sebagaimana dikutip oleh John (2004) mengemukakan bahwa labour welfare is the voluntary efforts of the employers to establish, within the existing industrial system, working and sometimes living and cultural conditions of the employees beyond what is required by law, the custom of the industry and the conditions of the market. Definisi kesejahteraan pekerja/buruh di Indonesia berdasarkan Undang-Undang Ketenagakerjaan adalah suatu pemenuhan kebutuhan dan/atau keperluan yang bersifat jasmaniah dan rohaniah, baik di dalam maupun di luar hubungan kerja, yang secara langsung atau tidak langsung dapat mempertinggi produktivitas kerja dalam lingkungan kerja yang aman dan sehat.

Selain untuk meningkatkan kesejahteraan, terdapat berbagai dampak dari upah minimum. Berbagai literature mengenai upah minimum menunjukkan bahwa upah minimum dapat mempengaruhi penghasilan, distribusi pendapatan, kemiskinan, inflasi, dan pengangguran. Namun sebagaimana menurut Herr et.al (2009), selalu terdapat perdebatan mengenai pendekatan teori dan hasil empiris dalam kajian upah minimum. Golan (2001) mengutip dari berbagai sumber mengemukakan bahwa kenaikan upah minimum akan mengurangi lapangan pekerjaan (Neumark and Wascher 1992, 2000; Currie and Fallick 1996; Abowd et al. 1999; and Neumark et al. 2000). 
Akpansung (2014) mengutip dari Adams (1987), meneliti efek makroekonomi dari upah minimum di Amerika Serikat. Adams menemukan bahwa Kenaikan upah minimum akan memiliki peningkatan yang sesuai pada tingkat harga dan pengangguran. Temuan Adam adalah sama dengan Brown et al (1982), yang menggunakan regresi time series untuk menganalisis efek dari upah minimum terhadap lapangan pekerjaan dan pengangguran. Mereka menemukan bahwa besarnya dampak minimum upah pada pekerjaan dan pengangguran tergantung pada situasi ekonomi yang berlaku, meskipun temuan menunjukkan hubungan positif antara upah minimum dan pengangguran, dan hubungan negatif antara upah minimum dan lapangan pekerjaan. Sabia sebagaimana dikutip oleh Akpansung (2014) mengemukakan bahwa kenaikan 10 persen dari upah minimum negara dikaitkan dengan penurunan 1 persen pekerja ritel dan pengurangan 1 persen dalam pekerjaan industri kecil. Meskipun demikian studi oleh Neumark et al. (2005) dan Burkhauser dan Sabia (2004) sebagaimana dikutip oleh Akpansung (2014) menunjukkan bahwa menaikkan upah minimum adalah alat kebijakan untuk membantu pekerja berketerampilan rendah.

Terdapat juga berbagai literature mengenai efek upah minimum terhadap distribusi pendapatan. Neumark et al. (1997) sebagaimana dikutip Golan (2001) mengemukakan efek upah minimum terhadap redistribusi pendapatan. Kenaikan upah minimum mungkin relatif mengurangi pendapatan keluarga miskin karena efek pengangguran terkonsentrasi di kalangan keluarga berpenghasilan rendah.

Herr et.al (2009) mengemukakan bahwa perdebatan muncul karena terdapat juga literature yang mengemukakan bahwa tidak terdapat efek terhadap lapangan pekerjaan dari peningkatan upah minimum. Seperti penelitian yang dilakukan oleh Card (1992), Benhayoun (1994), Card/Krüger (1995,1998 and 2000), Bell(1995). Namun studi lain mendukung teori neoklasik bahwa peningkatan upah minimum berdampak pada penurunan lapangan pekerjaan, yaitu seperti Bazen/Martin (1991), Currie/Fallick (1996), Chapple (1997), Orazem/Mattila (1998),
Neumark/Wascher (2000), Machin/Wilson (2004).

\section{Metode Penelitian}

Metode penelitian yang digunakan dalam penelitian ini adalah melalui pendekatan kualitatif. Peneliti merupakan instrumen dalam pengumpulan data. Data dalam penelitian ini bersumber dari hasil wawancara dan studi dokumentasi (Dokumen dari Dinas Tenaga Kerja Kabupaten Bandung dan Badan Pusat Statistik). Informan dalam penelitian ini adalah : (1) Pekerja/buruh sector industry besar dan sedang di Kabupaten Bandung (2) Pengusaha sector industry besar dan sedang di Kabupaten Bandung (3) Serikat pekerja di Kabupaten Bandung (4) Asosiasi Pengusaha Indonesia (Apindo) Kabupaten Bandung (5) Pengawas ketenagakerjaan, Dinas Tenaga Kerja Kabupaten Bandung.

Teknik validasi data melalui konfirmasi dari pernyataan para informan dan dokumendokumen yang dikaji. Pengujian data dalam teknik triangulasi merupakan crosscheck terhadap data yang diperoleh. Analisis data meliputi mempersiapkan data, coding, membuat narasi, dan interpretasi.

\section{Hasil dan Pembahasan}

\section{Upah Minimum sebagai Jaring Pengaman Upah bagi Pekerja/Buruh}

Penetapan upah minimum di Indonesia dimaksudkan untuk melindungi upah pekerja/buruh agar tidak merosot pada tingkat yang paling rendah sebagai akibat ketidakseimbangan pasar kerja, atau dengan kata lain upah minimum merupakan jaring pengaman upah bagi pekerja/buruh. Upah Minimum merupakan upah bulanan terendah yang terdiri atas upah pokok termasuk tunjangan tetap. Upah minimum juga hanya berlaku bagi pekerja/buruh yang mempunyai masa kerja kurang dari satu tahun. Penelitian ini difokuskan pada pelaksanaan upah minimum tahun 2015. Besaran upah minimum Kabupaten Bandung 
tahun 2015 berdasarkan SK Gubernur Jawa Barat adalah sebesar Rp.2.041.000, sedangkan rekomendasi dari Bupati sebesar Rp.2.001.195,00.

Hasil penelitian menunjukkan bahwa upah pekerja/buruh mengalami kenaikan setiap tahun, namun dalam pelaksanaan pembayaran upah tersebut tidak sesuai dengan ketentuan. Dari hasil wawancara dengan 4 pekerja/buruh dalam satu perusahaan industry besar yang sama diketahui bahwa Pekerja/buruh yang baru bekerja selama 8 bulan di perusahaan industry besar ini mendapatkan upah sebesar Rp. 1.623.086. Nilai upah tersebut tentu saja berada dibawah upah minimum. Selain itu diketahui juga bahwa upah untuk masa kerja lebih dari satu tahun, disamaratakan tanpa memperhatikan masa kerja, status pernikahan, ataupun status pekerja. Besaran upah perbulan yang diterima oleh pekerja/buruh sebesar Rp. 2.000.000,00 untuk masa kerja lebih dari 1 tahun, bahkan pekerja/buruh dengan masa kerja selama 5,5 tahun dan 12 tahun mendapatkan upah yang sama sebesar Rp.2.0000.000,00. Besaran tersebut juga diberlakukan sama, baik untuk pekerja tetap maupun pekerja kontrak. Jika melihat pada besaran upah, maka besarannya sama dengan upah minimum. Namun jika melihat masa kerja, seharusnya pekerja dengan masa kerja lebih dari 1 tahun mendapatkan upah lebih besar besar daripada upah minimum, dimana besaran upah disesuaikan dengan skala upah di perusahaan.

Penulis membandingkan pola pembayaran upah ini dengan perusahaan industry besar lainnya. Terdapat empat perusahaan industry besar lainnya yang menerapkan pola yang sama dalam pembayaran upah. Berdasarkan enam pekerja/buruh dari empat perusahaan indutri besar ini diketahui bahwa terdapat pemerataan dalam pembayaran upah tanpa melihat masa kerja, status pernikahan, atau status pekerja. Besaran upah yang diterima pekerja/buruh di 4 perusahaan industry besar ini adalah sebesar Rp. 2.041.000,00. Besaran upah tersebut disamaratakan, baik pekerja dengan masa kerja hampir 1 tahun, 2 pekerja dengan masa kerja 10 tahun, 2 pekerja dengan masa kerja 13 tahun, bahkan 20 tahun. Besaran tersebut juga disamaratakan untuk jabatan operator maupun group leader. Selain masa kerja, besaran tersebut juga tanpa melihat status pernikahan pekerja, yaitu lajang dan menikah dengan mempunyai anak. Besaran upah tersebut juga disamaratakan antara pekerja dengan status pekerja kontrak maupun pekerja tetap.

Namun terdapat juga perusahaan industry besar yang menerapkan pola yang berbeda. Berdasarkan hasil wawancara dengan lima pekerja dari dua perusahaan industry besar, diketahui terdapat perbedaan upah diantara pekerja/buruh dengan masa kerja yang berbeda. Pekerja dengan jabatan sebagai satpam dengan masa kerja 2 tahun mendapat upah sebesar Rp. 2.100.000,00. Sedangkan pekerja lain dalam jabatan yang sama dengan masa kerja selama 10 tahun mendapatkan upah sebesar Rp. 3.000.000,00. Pekerja dengan jabatan yang sama sebagai operator dengan masa kerja 1 tahun dan 6 tahun mendapatkan upah yang sama sebesar Rp.2.400.000,00. Meskipun tetap disamaratakan, namun besaran tersebut lebih tinggi dibanding dengan perusahaan sebelumnya. Sedangkan pekerja lain dengan jabatan sebagai Supervisor dengan masa kerja selama 8 tahun mendapat upah sebesar Rp. 3.735.000,00.

Dua perusahaan industry besar tersebut memberikan upah yang lebih tinggi. Namun tidak demikian bagi pekerja dengan masa kerja kurang dari satu tahun. Berdasarkan hasil wawancara dengan 5 pekerja pada satu perusahaan diketahui bahwa pekerja dengan masa kerja 5 bulan mendapatkan upah sebesar Rp.1.200.000. Tentu saja nilai tersebut berada dibawah ketentuan upah minimum. Namun pada perusahaan ini, pekerja dengan jabatan sebagai montir dengan masa kerja 9 tahun mendapat upah sebesar Rp.3.100.000.

Dalam hal komponen upah minimum yang merupakan upah bulanan terendah yang terdiri atas upah pokok termasuk tunjangan tetap, dari 32 informan pekerja sector industry besar diketahui bahwa upah yang diterima merupakan upah pokok saja. Tambahan komponen lainnya adalah uang makan dengan besaran Rp.4.000,00 - Rp.10.000,00 per hari, atau terdapat perusahaan yang memberikan dalam bentuk fasilitas makan. Terdapat juga perusahaan yang memberikan tambahan uang 
transport. Komponen uang makan dan transport tersebut tidak termasuk tunjangan tetap karena diberikan berdasarkan kehadiran.

Dapat disimpulkan bahwa pada perusahaan industry besar terdapat pola yang berbeda antara satu perusahaan dengan perusahaan lainnya. Namun demikian, pekerja dengan masa kerja kurang dari satu tahun mendapat upah dibawah upah minimum, atau tidak sesuai dengan ketetapan upah minimum. Sedangkan pekerja dengan masa kerja lebih dari satu tahun, yang seharusnya lebih besar dari upah minimum, mendapatkan upah sebesar upah minimum. Pemberian upah juga disama ratakan baik pekerja baru maupun pekerja dengan masa kerja lama, atau baik sudah menikah maupun belum menikah. Namun terdapat juga perusahaan yang memberikan upah lebih tinggi dibandingkan dengan perusahaan lainnya. Perusahaan ini juga membedakan upah antara masa kerja yang baru dengan masa kerja yang lama.

Pola yang berbeda terdapat dalam perusahaan industry sedang. Berdasarkan hasil wawancara dengan 2 pekerja pada 1 perusahaan industry sedang diketahui bahwa pembayaran upah pada perusahaan industry sedang tidak sesuai dengan hasil penetapan upah minimum. Besaran upah untuk pekerja dengan masa kerja kurang dari 1 tahun yaitu sebesar Rp. 300.000/minggu atau sebesar Rp. 1.200.000,00 per bulan. Sedangkan pekerja dengan masa kerja 11 tahun mendapatkan upah sebesar Rp. 450.000/minggu atau sebesar Rp. 1.800.000,00 per bulan. Besaran upah tersebut lebih kecil dari besaran upah minimum.

Bagi pengusaha industry sedang, mereka telah membayar upah dengan layak karena berdasar pada kondisi perkembangan usaha dan juga kondisi pendidikan dan keahlian pekerjanya. Pengusaha industry sedang menetapkan besaran dalam pengupahan pekerja, dimana besaran upah adalah Rp.250.000-300.000/minggu bagi pekerja baru. Sedangkan bagi pekerja yang sudah lama adalah Rp.350.000-500.000/minggu. Besaran uang lembur adalah Rp.7.000/jam. Perusahaanya tidak mengikuti ketentuan upah minimum, namun mempunyai skala upah tersendiri dilihat dari efektivitas dan kemampuan kerja karyawannya. Untuk setiap tahunnya setiap karyawan pasti memiliki kenaikan upah masingmasing tetapi tidak berdasarkan pada UMR, karena perusahaan juga memberikan hadiah kepada karyawan yang memiliki loyalitas terhadap perusahaan. Pengusaha industry sedang juga mengemukakan kesediannya untuk mengikuti ketentuan upah minimum yang telah ditetapkan. Namun kesediaan tersebut jika nanti kondisi usahanya sama dengan kondisi perusahaan besar.

Pengusaha industry sedang mempersoalkan mengenai besaran upah minimum yang diberlakukan sama rata untuk semua perusahaan, padahal kenyataannya terdapat perbedaan kemampuan antara perusahaan industry sedang dan perusahaan besar. Sehingga berdasar pada hal tersebut, pengusaha industry sedang tidak mengikuti ketetapan upah minimum dalam pembayaran upah. Pengusaha industry sedang tidak memiliki standar dalam penetapan upah. Mereka hanya melihat dari besaran yang biasanya berlaku di wilayah tersebut. Berbeda dengan perusahaan besar yang memang memperhatikan ketentuan upah minimum. Bagi pengusaha industry sedang, mereka tidak memperhatikan standar upah minimum karena sebagian besar pekerja yang direkrut hanya lulusan SMP, bahkan lulusan SD. Hanya sebagian kecil yang berasal dari lulusan SMA. Pekerja tersebut tidak mempunyai keahlian khusus pada saat direkrut. Berdasar alasan tersebut juga, pengusaha industry sedang mengemukakan bahwa mereka tidak menerapkan ketentuan upah minimum.

Pendidikan pekerja merupakan salah satu alasan tidak dilaksanakannya ketetapan upah minimum. Berdasarkan data informan dari 22 pekerja, sebagian besar pekerja pada perusahaan industry besar adalah berlatar belakang pendidikan SMA, yaitu 18 informan berlatar belakang SMA dan 2 informan berlatar belakang SMP. Sedangkan informan pada perusahaan industry industry sedang berlatar belakang SMP dan SD. Berkaitan dengan tingkat pendidikan pekerja di Kabupaten Bandung, berdasarkan data Statistik Daerah Kabupaten Bandung Tahun 
2015 diketahui bahwa tingkat pendidikan di Kabupaten Bandung masih didominasi oleh pendidikan SD dan belum tercapai pendidikan dasar 9 tahun.

Berdasarkan keterangan dari berbagai pihak, diketahui bahwa terdapat banyak pekerja yang dibayar tidak sesuai dengan ketetapan upah minimum. Sudah menjadi anggapan bahwa upah pekerja adalah sama dengan nilai upah minimum, namun disamakan baik untuk pekerja lajang maupun sudah menikah dan mempunyai anak. Diperkirakan hanya $40 \%$ perusahaan yang melaksanakan ketetapan upah minimum. Meskipun banyak terjadi pelanggaran dalam pembayaran upah, namun terdapat juga perusahaan yang melaksanakan sesuai dengan aturan pengupahan. Perbedaan pembayaran upah tersebut tergantung dari perusahaannya sendiri. Jika perusahaan mampu maka akan membayar sesuai dengan upah minimum. Tetapi sebagian besar perusahaan-perusahaan yang lain, masih melakukan negosiasi, bahkan masih banyak dibawah nilai upah minimum.

Terdapat kondisi lain dalam pelaksanaan upah minimum yaitu terdapatnya perjanjian di bawah tangan. Kondisi ini telah diakui oleh berbagai pihak. Karena ketidakmampuan perusahaan untuk membayar upah minimum sesuai ketentuan, maka dilakukan perjanjian dibawah tangan, yaitu perjanjian antara pengusaha dan serikat pekerja mengenai nilai upah yang nilainya dibawah upah minimum. Hal tersebut dilakukan agar perusahaan dapat tetap beroperasi.

Pengawas Ketenagakerjaan Dinas Tenaga Kerja merupakan unit yang terkait langsung dalam pengawasan pelaksanaan ketetapan upah minimum. Namun memang terdapat kesulitan untuk menentukan jumlah pasti berapa banyak pekerja yang dibayar tidak sesuai dengan ketentuan. Hal tersebut karena banyak perusahaan yang tidak melapor kepada Disnaker. Diluar dari laporan tersebut, mungkin banyak kasus yang tidak terdata. Dikemukakan bahwa perusahaan tidak membayarkan upah seuai dengan ketentuan, karena perusahaan tersebut mengajukan penangguhan yang memang diatur oleh peraturan. Namun kondisi diperparah karena terdapat perjanjian dibawah tangan. Perjanjian tersebut melanggar karena tidak sesuai dengan peraturan. Pengawas sendiri mempertanyakan mengapa perusahaan tidak mengajukan penangguhan, padahal sudah mendapat persetujuan dari Serikat Pekerja. Keengganan perusahaan tidak mengajukan penangguhan karena tidak mau untuk dilakukan audit keuangan.

Berkaitan dengan ketidakmampuan pengusaha dalam membayar upah minimum, telah diatur dalam pasal 90 UU No. 13 Tahun 2003, bahwa pengusaha dilarang membayar upah lebih rendah dari upah minimum. Bagi pengusaha yang tidak mampu membayar upah minimum, dapat dilakukan penangguhan. Penangguhan tersebut diatur lebih lanjut dalam Kepmen No. 231 Tahun 2003 Tentang Tata Cara Penangguhan Pelaksanaan Upah Minimum. Berdasarkan Kepmen tersebut bahwa permohonan penangguhan didasarkan atas kesepakatan tertulis antara pengusaha dengan pekerja/buruh atau serikat pekerja/serikat buruh yang tercatat. Adapun bentuk penangguhan yang telah mendapat izin dari Gubernur adalah : a. Membayar upah minimum sesuai upah minimum yang lama, atau; b. Membayar upah minimum lebih tinggi dari upah minimum lama tetapi lebih rendah dari upah minimum baru, atau ; c. Menaikkan upah minimum secara bertahap.

Jika diamati dari data, maka terdapat sedikit perusahaan yang mengajukan penangguhan. Dari jumlah perusahaan yang mengajukan penangguhan tersebut, perusahaan yang diberi izin penangguhan, lebih sedikit jumlahnya. Pada tahun 2012 terdapat 4 perusahaan yang mengajukan penangguhan, dann seluruhnya diberi izin penangguhan. Pada tahun 2013 terdapat 5 perusahaan yang mengajukan penangguhan dan 4 yang diberi izin penangguhan. Pada tahun 2014 terdapat 7 perusahaan yang mengajukan penangguhan dan hanya 3 yang diberi izin penangguhan. Pada tahun 2015 hanya terdapat 3 perusahaan yang mengajukan penangguhan dan seluruhnya diberi izin penangguhan. (Sumber : Dinas Tenaga Kerja Kabupaten Bandung).

Mengenai sedikitnya jumlah perusahaan 
yang mengajukan penangguhan, dapat dipahami karena proses penangguhan yang rumit. Terddapat beberapa persyaratan yaitu pertama harus ada kesepakatan, kedua harus ada audit dari akuntan publik, ketiga ada neraca rugi laba, keempat daftar upah dari jabatan terendah sampai tertinggi. Kebanyakan perusahaan tidak mau melakukan prosedur tersebut karena tidak mau diaudit. Karena banyak perusahaan yang tidak mau mengikuti penangguhan, sehingga dilakukan perjanjian di bawah tangan.

Kondisi perjanjian dibawah tangan antara serikat pekerja dan pengusaha dalam pembayaran upah ini menyebabkan pelanggaran dalam upah sulit untuk ditindak. Perjanjian tersebut tidak dibenarkan oleh aturan karena berisi mengenai besaran upah dimana nominalnya berbeda dalam arti lebih rendah dari upah minimum yang telah ditetapkan. Dalam pasal 91 UU 13 Tahun 2003 Tentang Ketenagakerjaan dinyatakan bahwa pengaturan pengupahan yang ditetapkan atas kesepakatan antara pengusaha dan pekerja/buruh atau serikat pekerja/serikat buruh tidak boleh lebih rendah dari ketentuan pengupahan yang ditetapkan peraturan perundang-undangan yang berlaku. Namun demikian pihak pengawas kesulitan dalam memberikan sanksi tersebut karena terdapat perjanjian antara Serikat pekerja dan pengusaha. Sehingga pelanggaran upah sulit ditindak karena pekerja bersedia dibayar dengan upah dibawah upah minimum.

Pengawas ketenagakerjaan mengemukakan bahwa sanksi terhadap pelanggaran upah minimum sudah diatur dalam aturan. Namun terdapat hal-hal lain untuk dapat menetapkan sanksi tersebut. Sulit bagi pengawas karena jika menetapkan sanksi maka perusahaan menjadi tutup dan terjadi PHK secara massal. Sehingga tindakan yang dilakukan pengawas selama ini adalah pembinaan. Dikemukakan juga bahwa upah minimum adalah untuk pekerja dengan masa kerja kurang dari 1 tahun. Jika lebih dari 1 tahun mengikuti skala upah. Namun pelanggaran terhadap skala upah memang tidak ada sanksi dalam peraturan. Sehingga pengawas tidak dapat berbuat banyak karena memang tidak terdapat sanksi terhadap pelanggaran skala upah.

Jika merujuk pada Eyraud dan Saget
(2005:40), tujuan penetapan upah minimum adalah untuk melindungi pekerja pada level terendah, untuk menjamin mereka sesuai standar hidup yang layak. Pekerja pada level terendah ini diartikan pemerintah Indonesia dengan pekerja dengan masa kerja kurang dari 1 tahun. Selanjutnya jika merujuk pada Eyraud dan Saget (2005:41), penetapan upah minimum pada metode awalnya ditetapkan menurut kemampuan pengusaha untuk membayar, dimana produktivitas (PDRB) tidak dihitung dalam perhitungan upah minimum. Upah minimum ini dihitung dari kebutuhan dasar pekerja untuk membayar biaya hidup mereka sendiri dan keluarga mereka.

Perhitungan KHL di Indonesia memang hanya berdasarkan atas kebutuhan pekerja lajang, tidak ditambah dengan kebutuhan keluarga pekerja. Berdasarkan informan dari pekerja/buruh, upah yang diterima bagi pekerja lajang sudah dapat mencukupi kebutuhan dasar sehari-hari. Namun berbeda dengan pekerja/buruh yang sudah berkeluarga dan memiliki anak, upah yang diterimanya tidak dapat mencukupi kebutuhan dasar sehari-hari. Sehingga terdapat kecenderungan bagi pasangan pekerja/buruh untuk bekerja atau membuka usaha untuk mencukupi kebutuhan sehari-hari. Namun demikian kebutuhan untuk menabung tidak dapat terpenuhi. Demikian juga dengan kebutuhan sekunder dan tersier yang kurang terpenuhi, seperti kendaraan dan rumah yang layak.

Dengan demikian, permasalahan dalam pelaksanaan penetapan upah minimum adalah pembayaran upah yang relative sama rata diantara pekerja. Dimana besarnya upah tersebut adalah sama dengan upah minimum. Sedangkan perhitungan upah minimum sendiri dihitung dari kebutuhan hidup layak untuk pekerja lajang. Kondisi tersebut mendorong unjuk rasa secara besar-besaran pada penetapan upah tahun selanjutnya. Sudah menjadi pandangan bahwa upah minimum adalah sama dengan upah bagi pekerja. Sehingga dengan demikian, proses penetapan upah minimum menjadi sangat penting bagi pekerja dan juga serikat pekerja/buruh. 
Menyikapi permasalahan tersebut terdapat beberapa harapan yang ditujukan kepada pemerintah. Sebenarnya pekerja/buruh tidak menginginkan upah yang terlalu besar atau terlalu kecil. Namun harapan pekerja/buruh adalah kenyaman dalam nilai upah yang diterima untuk dapat memenuhi kebutuhan hidup seharihari. Kenyamanan apabila terjadi kestabilan harga. Kenaikan upah yang diikuti dengan kenaikan harga tidak akan dirasakan manfaatnya. Sehingga tidak masalah jika tidak terjadi kenaikan upah asalkan tidak terjadi kenaikan harga.

Salah satu peran pemerintah dalam perekonomian adalah peran stabilitas. Dimana dalam pandangan pekerja, terdapat stabilitas harga terutama harga bahan-bahan pokok. Kenaikan upah minimum tidak dirasakan manfaatnya karena diiringi dengan kenaikan harga. Jika dilihat dari kondisi perekonomian Kabupaten Bandung Tahun 2012-2015, PDRB perkapita ADH berlaku Kabupaten Bandung terus menunjukkan peningkatan, atau rata-rata tumbuh sebesar $11,67 \%$ per tahun. Namun tidak demikian dengan tingkat pertumbuhan PDRB perkapita $\mathrm{ADH}$ konstan yang menggambarkan pendapatan riil penduduk, dimana tingkat pertumbuhannya termasuk kecil yaitu $4,1 \%$ per tahun. Rendahnya PDRB perkapita ADH konstan tersebut disebabkan karena inflasi. Dengan demikian, tuntutan kenaikan upah minimum dari serikat pekerja/serikat buruh dapat diredam jika pemerintah mampu untuk menjaga stabilitas harga.

\section{Perkembangan Usaha}

Sebagaimana dinyatakan dalam penjelasan UU No.13 Tahun 2003, pembangunan ketenagakerjaan harus diatur sedemikian rupa sehingga terpenuhi hak-hak dan perlindungan yang mendasar bagi tenaga kerja dan pekerja/buruh serta pada saat yang bersamaan dapat mewujudkan kondisi yang kondusif bagi pengembangan dunia usaha.

Terkait dengan pengembangan dunia usaha, diketahui bahwa terdapat berbagai hambatan yang dihadapi oleh pengusaha.
Dikemukakan bahwa Laju Pertumbuhan Ekonomi Kabupaten Bandung memang mengalami penurunan, tetapi tidak semua dunia usaha sedang lesu. Ada beberapa jenis usaha yang untuk saat ini (2015 akhir dan 2016) sedang bagus, yaitu industry yang melakukan eksport. Untuk perusahaan lokal, terdapat beberapa jenis perusahaan yang mengalami kemunduran yaitu printing dan tenun. Perusahaan tersebut menggunakan teknologi sederhana sehingga kalah bersaing dengan produk dari Cina. Produk Cina lebih bagus dan lebih murah karena pemerintah Cina memberikan subsidi eksport. Selain itu, terdapat pasar bebas dan banyak barang selundupan dari tekstil yang tidak pernah diberantas sehingga produk local kalah bersaing.

Selain terkait dengan daya saing perusahaan, biaya juga menjadi factor utama dalam perkembangan dunia usaha. Dari nilai upah minimum yang ditetapkan, sebenarnya biaya upah lebih dari yang ditetapkan karena pengusaha mendapat tambahan biaya dengan membayar BPJS kesehatan sebesar 4\%, BPJS ketenagakerjaan 3,7\%. Belum lagi ditambah dengan biaya pensiun, transport dan uang makan. Jika dilihat dari komposisi terbesar dalam biaya operasional, biaya terbesar operasional bagi perusahaan adalah biaya bahan baku dan bahan baku pendukung. Biaya upah memang lebih kecil daripada biaya bahan baku dan bahan baku pendukung. Namun, kenaikan upah minimum akan mendorong kenaikan harga bahan baku dan bahan baku pendukung. Contohnya adalah perusahaan dengan bahan baku benang, ketika membeli benang harganya akan naik karena penyedia benang harus membayar kenaikan upah. Sehingga dengan kenaikan upah akan mendorong kenaikan harga bahan baku, bahan baku pendukung dan operasional lainnya. Biaya operasional lainnya adalah listrik, karena perusahaan beroperasi menggunakan listrik. Berikut adalah data biaya input perusahaan besar dan sedang di Kabupaten Bandung pada tahun 2012 dan 2013. 
Tabel 1 Biaya Input Perusahaan Besar dan Sedang di Kabupaten Bandung (dalam ribuan rupiah)

\begin{tabular}{|l|r|c|}
\hline \multicolumn{1}{|c|}{ Komponen } & Tahun 2012 & Tahun 2013 \\
\hline Bahan baku & 19.681 .994 .109 & 17.719 .419 .449 \\
\hline Upah & 3.131 .805 .892 & 3.262 .574 .460 \\
\hline Komponen upah lainnya & 530.860 .250 & 422.390 .991 \\
\hline Listrik & 1.796 .375 .789 & 1.832 .474 .999 \\
\hline Bahan bakar dan pelumas & 1.052 .795 .798 & 902.116 .778 \\
\hline Sewa gedung dan mesin & 88.468 .801 & 123.995 .648 \\
\hline Pembelian/penambahan modal tetap & 1.426 .780 .027 & 1.912 .151 .873 \\
\hline Nilai tambah perusahaan & 15.831 .449 .112 & 19.049 .440 .472 \\
\hline Nilai tambah (keuntungan) per pekerja & 91.140 & 115.519 \\
\hline Tingkat efisiensi (\%) & 39,09 & 45,87 \\
\hline
\end{tabular}

Sumber : Statistik Industri Besar dan Sedang Jawa Barat 2012 dan Statistik Industri Besar dan Sedang Jawa Barat 2013. BPS Provinsi Jawa Barat

Berdasarkan table tersebut, diketahui pada tahun 2012 dan 2013, komponen biaya terbesar bagi perusahaan adalah bahan baku. Biaya selanjutnya adalah upah beserta komponen lainnya. Biaya selanjutnya adalah listrik, yang mengalami kenaikan dari tahun 2012 ke 2013. Bahan bakar dan pelumas serta sewa gedung dan mesin merupakan komponen biaya selanjutnya. Dari tahun 2012 ke 2013 terdapat pembelian dan penambahan modal tetap perusahaan, demikian juga dari sewa gedung, mesin dan listrik mengalami kenaikan. Sehingga terdapat inovasi dari pengusaha dengan pengadaan mesin atau modal lainnya. Dilihat dari nilai tambah (keuntungan) perusahaan, terdapat kenaikan dari tahun 2012 ke tahun 2013, demikian juga dari segi efisiensi terdapat peningkatan dari tahun 2012 ke tahun 2013. Berdasarkan hasil wawancara, kondisi untuk tahun 2015 dalam hal urutan biaya input kurang lebih sama dengan tahun sebelumnya.

Namun nilai tersebut belum memperhitungkan hambatan lain yang dihadapi pengusaha. Biaya lainnya yang memberatkan bagi pengusaha adalah 'biaya siluman'. Biaya tersebut terdapat dalam kegiatan eksport import dan kegiatan bea cukai lainnya. Selain itu, terdapat 'biaya siluman' dalam setiap tahap mulai dari perizinan sampai dengan pengawasan dan lain sebagainya, membuat biaya menjadi semakin mahal. Demikian juga ketika banyak perusahaan yang tidak melakukan wajib lapor perusahaan, atau tidak melakukan penangguhan pelaksanaan upah minimum karena pengusaha harus membayar biaya kepada oknum.

Pengusaha juga mengemukakan bahwa birokrasi di Indonesia sangat sulit, yaitu pengurusan izin dengan waktu yang sangat lama. Walaupun telah ada pengurusan ijin terpadu, namun perubahan tidak dirasakan oleh pengusaha karena pengurusan izin tetap memerlukan waktu yang lama. Sehingga upaya reformasi perizinan yang dilakukan pemerintah hanya secara konsep saja karena dalam pelaksanaannya tidak tercapai. Selain itu sector industry juga dihadapkan pada pajak yang tinggi yang dipungut oleh pemerintah. Sehingga pihak pengusaha sangat berharap kepada pemerintah karena terdapat factor-faktor yang memang memerlukan campur tangan pemerintah.

Terdapat perusahaan yang memang mengalami perkembangan Hal tersebut dilihat dari posisi eksport yang terus meningkat dan penambahan produk. Produksi mengalami peningkatan disebabkan karena perusahaan melakukan inovasi baru dengan melakukan pembelian mesin baru, meskipun mesin tersebut import dari Cina. Penambahan mesin baru 
tersebut menciptakan inovasi baru dalam dunia textile dimana sebelumnya hanya bergerak di bidang polyester murni menghasilkan kain-kain, sekarang tercipta produk baru yaitu pada jenis kain semacam kaos atau jersey

Kondisi perusahaan besar tersebut berbeda dengan kondisi perusahaan industry sedang. Bagi perusahaan industry sedang, usaha mengalami penurunan disebabkan karena persaingan usaha dan banyaknya barang import di Indonesia sehingga menyebabkan penurunan pesanan dari beberapa distributor lokal. Selama ini, kemudahan yang dikemukakan pemerintah tidak direalisasikan karena pada kenyataannya dalam mengurus izin usaha atau distribusi barang harus ada uang untuk melancarkan berjalannya kegiatan perusahaan. Sehingga pembayaran tersebut dirasakan berat oleh pengusaha. Pajak dianggap pembayaran yang memberatkan, namun pengusaha mengeluarkan pembayaran tersebut karena dianggap keharusan.

Kenaikan upah minimum, berbagai beban biaya dan hambatan yang dihadapi oleh pengusaha berdampak pada pengurangan jumlah pekerja. Berdasarkan data dari Dinas Tenaga Kerja Kabupaten Bandung, pada tahun 2015 di Kabupaten Bandung terdapat PHK massal yang jumlahnya meningkat dibanding dengan tahun sebelumnya. Pada tahun 2015 terdapat 6 kasus PHK massal yang melibatkan 3.766 pekerja. Dibanding tahun 2014 dimana terdapat 6 kasus PHK massal namun melibatkan 262 pekerja. Dikemukakan pihak pengusaha bahwa banyak perusahaan yang merumahkan karyawannya. Hal tersebut dilakukan karena perusahaan tidak mendapatkan pesanan (order) namun stok menumpuk di gudang, sehingga perusahaan menghentikan produksi dan merumahkan sementara pekerjanya. PHK merupakan langkah terakhir namun pekerja tetap harus mendapatkan hak-haknya jika di PHK. PHK merupakan cara perusahaan untuk menyikapi situasi perekonomian. Perekonomian sedang lesu, Dollar menguat, daya beli masyarakat berkurang, dan harga bahan baku menjadi mahal.

Kenaikan upah minimum sangat berpengaruh terhadap perusahaan. Sehingga banyak strategi yang dilakukan oleh perusahaan. Salah satu strategi tersebut adalah terdapat pembayaran upah dibawah minimum melalui perjanjian bawah tangan, bukan melalui penangguhan. Pihak perusahaan mengemukakan bahwa mereka bisa saja membayar upah sesuai dengan ketetapan upah minimum namun akan melakukan efisiensi pekerja sebanyak $40 \%$. Sebetulnya perusahaan juga tidak menginginkan hal tersebut terutama kepada pekerja yang sudah lama bekerja di perusahaan, namun karena terkait dengan kemampuan membayar dari perusahaan, maka dilakukan beberapa strategi. Selain melakukan efisiensi, perusahaan juga dihadapkan pada masalah kurangnya permintaan (order) terhadap produksi. Karena tidak ada order dan terjadi kenaikan upah minimum, maka perusahaan melakukan PHK terhadap pekerja terutama pekerja kontrak. Selain memberhentikan pekerja kontrak, terdapat perusahaan besar lainnya yang melakukan relokasi ke Majalengka. Alasan relokasi tersebut karena upah minimum, dimana di Majalengka memiliki nilai upah minimum yang rendah. Bukan hanya Kabupaten Bandung, daerah lainnya seperti Kota Bandung, Kabupaten Bandung, Kota Bekasi , Kabupaten Karawang banyak yang melakukan relokasi.

\section{Kenaikan Upah Minimum dan Kondisi Ekonomi Makro Kabupaten Bandung}

Tabel 2. Nilai Upah Minimum dan Kondisi Ekonomi Makro Kabupaten Bandung Tahun 2012 - 2015

\begin{tabular}{|l|l|l|l|l|}
\hline & Tahun 2012 & Tahun 2013 & Tahun 2014 & Tahun 2015 \\
\hline Nilai Upah Minimum (Rp) & 1.223 .800 & 1.388 .333 & 1.735 .473 & 2.041 .000 \\
\hline LPE (\%) & 6,28 & 5,89 & 5,88 & 5,47 \\
\hline $\begin{array}{l}\text { Laju pertumbuhan PDRB } \\
\text { (sector industry) }\end{array}$ & $5,90 \%$ & $5,98 \%$ & $6,66 \%$ & $4,32 \%$ \\
\hline $\begin{array}{l}\text { PDRB ADHK sektor industry } \\
\text { (juta rupiah) }\end{array}$ & $27.583 .084,9$ & $29.232 .561,2$ & $31.179 .167,9$ & 32.526 .108 \\
\hline
\end{tabular}

Sumber : Diolah dari berbagai dokumen Badan Pusat Statistik dan SK Gubernur mengenai Upah Minimum 
Dari tahun 2012 sampai dengan tahun 2015, nilai upah minimum mengalami kenaikan. Namun dilihat dari nilai laju pertumbuhan ekonomi, Kabupaten Bandung mengalami perlambatan dalam setiap tahunnya. Perlambatan laju pertumbuhan ekonomi pada tahun 2015 salah satunya disebabkan karena perlambatan dalam sector industry. Kinerja sector industry sebagai sector dengan konstribusi PDRB terbesar menunjukkan kenaikan pada tahun 2012-2014. Namun pada tahun 2015 mengalami perlambatan walaupun masih bernilai positif.

Berdasarkan dokumen Analisis Pembangunan Ekonomi Tahun 2015, perlambatan sector industry terutama disebabkan oleh perlambatan per-tumbuhan sub sector industry tekstil, barang dari kulit dan alas kaki yang merupakan kontributor terbesar pada sektor industry pengolahan. Sehingga sedikit saja terjadi perubahan pada sub sektor ini akan memberikan pengaruh cukup signifikan terhadap sektor industry pengolahan. Kecenderungan penurunan kontribusi sector ini sejalan dengan peningkatan kontribusi sector ekonomi lain terutama sector perdagangan, hotel dan restoran terhadap pembentukan PDRB total Kabupaten Bandung.

Kenaikan upah minimum menyebabkan kenaikan biaya bagi pengusaha, ditambah dengan biaya-biaya lainnya. Upaya yang dilakukan pengusaha agar tetap dapat melangsungkan usaha adalah dengan melakukan efisiensi dengan cara mengurangi pekerja. Kondisi di Kabupaten Bandung tersebut dapat dijelaskan berdasarkan teori neoklasik mengenai upah minimum. Sebagaimana dikemukakan oleh Herr et.al (2009:17), jika upah minimum berada di atas tingkat keseimbangan, maka perusahaan akan mengurangi pekerja sehingga akan berbahaya karena menciptakan pengangguran. Tingkat pengangguran ini menunjukkan kelebihan penawaran tenaga kerja. Jika dilihat dalam statistik ketenagakerjaan Kabupaten Bandung tahun 2013-2014, Kabupaten Bandung mengalami kenaikan pertambahan angkatan kerja yang sebanding dengan penduduk usia kerja. Tingkat pengangguran secara umum pada tahun 2014 adalah $8,48 \%$ yang menurun dari tahun sebelumnya sebesar 10,19\% di tahun 2013 .

Di Kabupaten Bandung, kelebihan penawaran tenaga kerja ini tidak selalu menunjukkan pengangguran yang meningkat, tetapi berpindahnya pekerja dari sector formal (yang terkover oleh kebijakan upah minimum) ke sektor informal (yang tidak terkover oleh kebijakan upah minimum). Hal tersebut dapat dilihat dari dengan kecenderungan penurunan kontribusi dari sector industry yang sejalan dengan peningkatan kontribusi sector ekonomi lain terutama sector perdagangan. Berdasarkan statistic daerah Kabupaten Bandung terdapat penurunan dalam sector industry dalam menyerap lapangan kerja, dimana penurunan tersebut sejalan dengan kenaikan dalam sector lain yaitu perdagangan, jasa, dan lainnya.

Jika dilihat dari segi produktivitas, maka produktivitas secara makro mengalami kenaikan. Produktivitas yaitu PDRB dibagi jumlah tenaga kerja. Demikian juga dalam table 1 dalam komponen nilai tambah per pekerja yang mengalami kenaikan. Namun menurut pengusaha, pekerja/buruh Kabupaten Bandung bahkan pekerja Indonesia masih kurang produktif. Alasan tersebut karena dibandingkan dengan negara lain seperti Vietnam, sebagai contoh pabrik sepatu di Vietnam dan di Indonesia. Pekerja Vietnam mampu menghasilkan 2,5 sepatu dalam 7 jam kerja sedangkan pekerja Indonesia hanya menghasilkan 0,8 sepatu. Sedangkan upah di Indonesia lebih tinggi daripada di Vietnam. Berdasarkan perhitungannya, bahwa produktivitas pekerja/buruh Kabupaten Bandung belum mencapai 100\%, sedangkan pengusaha tetap harus membayar upah $100 \%$. Produktivitas pekerja berkisar antara $50 \%$ sampai dengan $90 \%$ sehingga jika dirataratakan hanya sebesar $75 \%$. Perhitungan produktivitas tersebut dilihat dari kapasitas mesin terpasang, sehingga diketahui kapasitas dari suatu mesin dalam per jamnya. Kurang produktifnya pekerja Kabupaten Bandung disebabkan karena skill pekerja yang masing kurang baik. 


\section{Kesimpulan dan Saran}

Kondisi pembayaran upah minimum di Kabupaten Bandung tidak jauh berbeda dengan wilayah lain di negara berkembang lainnya. Upah minimum belum efektif sebagai alat perlindungan upah bagi pekerja/buruh. Terdapat banyak pekerja/buruh Kabupaten Bandung yang dibayar tidak sesuai dengan ketentuan upah minimum. Kondisi tersebut disebabkan karena : 1) Perbedaan kemampuan antara perusahaan industry besar, sedang dan kecil. 2) Rendahnya tingkat pendidikan pekerja. 3) Prosedur penangguhan upah seringkali tidak dilakukan oleh pengusaha, namun pengusaha lebih memilih untuk melakukan perjanjian dibawah tangan jika tidak mampu untuk membayar upah minimum. 5) Penegakkan sanksi sulit dilakukan karena kondisi perjanjian dibawah tangan dan data akurat mengenai pelanggaran upah minimum sulit diperoleh, Selain itu, penegakan sanksi dapat berdampak pada penutupan perusahaan dan pemutusan hubungan kerja.

Pembayaran upah minimum sangat tergantung pada kondisi perusahaan. Namun demikian, kondisi perkembangan dunia usaha di Kabupaten Bandung adalah : 1) Dunia usaha cenderung mengalami perlambatan, kecuali bagi perusahaan yang berorientasi eksport dan melakukan inovasi dalam pembelian mesin baru 2) Lemahnya daya saing perusahaan disebabkan banyaknya barangnya barang import 3) Meskipun bukan komponen biaya yang terbesar, namun kenaikan upah minimum akan mendorong kenaikan harga bahan baku dan bahan baku pendukung. 4) Terdapat beban biaya lainnya yang dibebankan kepada pengusaha. Tingginya pajak yang ditanggung pengusaha, dan banyaknya biaya tidak resmi dalam kegiatan usaha 5) Perizinan yang berbelit belit dan waktu yang lama. 6) Pekerja yang dianggap kurang produktif karena kurangnya keahlian.

Dari segi ekonomi makro, nilai upah minimum selalu mengalami kenaikan setiap tahunnya. Namun kenaikan tersebut tidak berarti karena disertai dengan inflasi. Demikian juga laju pertumbuhan ekonomi Kabupaten Bandung mengalami perlambatan yang banyak dipe- ngaruhi karena perlambatan laju PDRB sector industry. Banyaknya kasus pemutusan kerja tidak menyebabkan tingginya pengangguran di $\mathrm{Ka}$ bupaten Bandung. Namun beralihnya pekerjaan dari sector formal kepada sector informal.

Permasalahan upah minimum merupakan permasalahan kompleks yang memerlukan penanganan dari berbagai instansi pemerintah. Upah minimum dapat menjadi alat yang efektif bagi peningkatan kesejahteraan apabila terdapat upaya untuk mengatasi berbagai permasalahannya. Perkembangan dan kemudahan bagi dunia usaha sangat diperlukan untuk dapat meningkatkan produktivitas yang pada akhirnya akan meningkatkan Laju Pertubuhan Ekonomi. Diperlukan langkah-langkah yang realistis untuk dapat mengatasi berbagai hambatan yang dihadapi oleh pengusaha, terutama dalam mengatasi hambatan tingginya biaya non operasional. Pemerintah juga dihadapkan pada peningkatan pendidikan dan kemampuan pekerja di Kabupaten Bandung sehingga dapat lebih meningkatkan produktivitas. Selain itu, apabila fungsi stabilisasi harga dilaksanakan dengan baik, tidak menutup kemungkinan akan menurunkan tuntuan kenaikan upah minimum dari pekerja/buruh. Dapat dipertimbangkan juga pengupahan berdasarkan produktivitas, dimana terdapat tambahan upah (bonus) bagi pekerja yang memiliki produktivitas tinggi.

\section{DAFTAR PUSTAKA}

Akpansung, Aniekan Okon. 2014. An Empirical Assessment of the Effects of Minimum Wage Increases on Unemployment during Democratic Governance in Nigeria. International Journal of Humanities and Social Science Vol. 4, No. 13.

Bhorat, Haroon \& Stanwix, Benjamin. 2013. Minimum Wage Enforcement in the Developing World. Participants at the IZA World Of Labor Minimum Wage Workshop in Frankfurt, $4^{\text {th }}$ June 2013

Eyraud, Francois \& Saget, Catherine. 2005. The 
Fundamentals of Minimum wage Fixing.

Geneva : International Labour Office.

Golan, Amos. Perloff, Jeffrey \& Wu, Ximing. 2001. Welfare Effects of Minimum Wage and Other Government Policies

Gunderson, Morley. 2005. Minimum Wages in Canada : Theory, Evidence and Policy (Prepared for the Federal Labour Standards Review Commission)

Herr, Hansjorg. Kazandziska, Milka \& Mahnkopf, Silke. 2009. The Teoritical Debate About Minimum Wage. Global Labour University Working Paper. ISSN.1866-0541.

John, C.P. 2004. Social Security and Labour Welfare with Special Reference to Construction Workers in Kerala. Kerala Research Programme on Local Level Development Centre for Development Studies

Jones, Patricia. 1997. The Impact of Minimum Wage Legislation in Developing Countries where Coverage is Incomplete. Centre for the Study of African Economies Institute of Economics and Statistics. University of Oxford

Musgrave, Richard. A \& Musgarve, Peggy. B. 1989. Public Finance in Theory and Practice. Singapore : Mc Graw-Hill

Paitoonpong, Srawooth. Akkarakul, Nipanan \& Sukaruji, Chothiga. 2005. The Minimum Wage-fixing System in Thailand. Vol. 20 No. 2 Thailand Development Research Institute 